\title{
Exploring unknown life stages of Arctic Tanytarsini (Diptera: Chironomidae) with DNA barcoding
}

\author{
ELISABETH STUR ${ }^{1} \&$ TORBJØRN EKREM ${ }^{2}$ \\ Museum of Natural History and Archaeology, Norwegian University of Science and Technology, NO-7491 Trondheim, Norway. \\ E-mail: Elisabeth.Stur@vm.ntnu.no, ${ }^{2}$ Torbjorn.Ekrem@vm.ntnu.no
}

\begin{abstract}
We present the first results from a project on Spitsbergen and Bear Island where the ultimate goal is to provide genetic and morphological identification keys to all species. Five Tanytarsini species have been recorded from Svalbard. By sequencing partial COI gene sequences, we have associated larvae of all of these, and describe the hitherto undescribed larval stages of Microspectra insignilobus Kieffer, M. radialis Goetghebuer and Tanytarsus heliomesonyctios Langton. We also present keys to larva, pupa and imagines of all Tanytarsini species found on Svalbard and discuss larval morphology in relationship to characters preserved in subfossil material. Of particular interest is the mandible and mentum of T. heliomsonyctios which show close resemblance to the tentatively associated larvae of Corynocera oliveri Lindeberg. An overview over Tanytarsus species with "lugens-type" larvae is given and the phylogenetic value of mandibular accessory teeth is briefly discussed.
\end{abstract}

Key words: Chironomids, immature stages, descriptions, keys, Svalbard

\section{Introduction}

Chironomidae species are likely the most frequent and diverse macroinvertebrates in Arctic freshwater ecosystems and species level identifications of immatures, in particular larvae, are important for both biomonitoring and paleolimological studies. Nevertheless, knowledge of larvae belonging to Arctic species is limited and no up-to-date identification keys and literature for Arctic Chironomidae exists today.

Due to its accessibility and infrastructure, the Svalbard archipelago has become an attractive area to conduct environmental and climate studies in the high arctic. The activity calls for increased knowledge of the insect fauna, especially of the family Chironomidae. Since various paleolimnological and ecological studies use chironomids as indicator organisms, it is necessary to produce a reliable overview of and keys to the chironomid species in the area.

The study of chironomids from arctic islands has a long tradition. Several Swedish and a French expedition in the mid 18th century resulted in Boheman's (1865) "Spetsbergens Insekt-Fauna", and "Bidrag til Kännodomen om Beeren Eilands och Spetsbergens Insekt-Fauna" by Holmgren (1869). Kieffer and Thienemann (1919a, b) analysed the chironomid material from Koch's 1911 expedition, and Edwards (1922, 1924, 1925 \& 1935) followed by processing material from the Oxford University expeditions to Spitsbergen in the 1920s and Bear Island in 1932. Knowledge of arctic chironomids from Norwegian expeditions has been published by Goetghebuer (1933), and Oliver (1962) reviewed the Orthocladiinae of Bear Island - based on material from the Troms $\emptyset$ Museum's Bear Island Expedition in 1957.

Coulson \& Refseth (2004) presented an overview of the terrestrial and freshwater invertebrate fauna of Svalbard. In their list, class Insecta is represented by 230 species, including 128 Diptera and over 60 chironomids. The authors characterized their list of chironomids as a conservative estimate of the Svalbard fauna and addressed at the same time the need for taxonomic revisions of the most of the species found on Svalbard. Compared to the total number of chironomid species currently present on Svalbard, a high percentage were originally first described from the archipelago. We have counted 20 valid species names originally described from Svalbard. Some of these have later also been recorded elsewhere. But the true number of species that are endemic to the high arctic is difficult to evaluate since many genera are in need of taxonomic revision. 
Palaeoecologists working with Chironomidae use subfossil larval head capsules from sediment cores to identify chironomid communities back in time. Identification to genus-level and often species groups is usually possible and sufficient to make ecological inferences from subfossil chironomid assemblages (Brooks et al. 2007) However, correct identification to species level can be challenging since most of the remains usually consist of partial head capsules and since the larvae of many species still are unknown to science. As a result, a somewhat parallel taxonomy of morphotypes has been developed on the species-group level that occasionally has little to do with the systematics of the groups. One example is the Tanytarsus lugens-type larval mandible which is found in some but not all species from at least three different species groups. The larvae of the parthenogenetic Tanytarsus heliomesonyctios Langton described below further increases the number of species known to have multiple accessory teeth on the mandible.

It has been argued that species identification by DNA barcodes is particularly useful for taxonomic groups that are difficult to identify using morphology (Hebert et al. 2004). Many chironomids, especially larvae, certainly fall within this category and partial COI gene sequences have been shown appropriate to delimit and identify species as well as associate life stages in Chironomidae (Carew et al. 2005; Ekrem et al. 2007; Ekrem et al. 2010). One of the objectives of our current chironomid diversity survey on Svalbard therefore is to produce a DNA barcode library for all Arctic species. In addition to taxonomic reviews and updates we also aim to provide revised identification keys to all life stages. In this study we focus on some of our first findings regarding the tribe Tanytarsini.

\section{Material and methods}

Svalbard is located in the Arctic Ocean north of Scandinavia and covers a land area of approximately $61000 \mathrm{~km}^{2}$ (Prestrud et al. 2004). The archipelago consists of ten major islands and various islets and holms. Spitsbergen, placed between 76 and 80 degrees north, is the largest island of Svalbard, roughly $38000 \mathrm{~km}^{2}$. The material from Spitsbergen used in this study was collected in a relatively small area around Is-fjorden (Longyearbyen, Cape Linné and Adventdalen). Bear Island is the most southern part of Svalbard. It is located at 74 degrees northern latitude, half way between mainland Norway and Spitsbergen and has an area of $176 \mathrm{~km}^{2}$ (Norwegian Polar Institute 2009). The northern part of the island is relatively plain with numerous lakes and ponds while the south is mountainous with the $536 \mathrm{~m}$ high Mount Misery being the highest peak.

The material used in this study was collected by Malaise traps, sweep-nets, kick-sampling and core-sampling in various expeditions and field trips to Svalbard. Immature chironomids were preserved in $96 \%$ pure ethanol while imagines were kept in slightly dilute ethanol $(\sim 80-85 \%)$ to avoid breakage. Tissue for DNA extraction and sequencing was sampled under a stereo microscope and shipped to the Canadian Centre for DNA Barcoding at the University of Guelph (CCDB, www.dnabarcoding.ca). The remainder of most sampled specimens were macerated in $\mathrm{KOH}$ and slide mounted in Euparal. Numerous other specimens are still preserved in ethanol and stored at $5^{\circ} \mathrm{C}$.

Species identification was based on available literature (Brundin 1949; Langton 1998; Reiss \& Säwedal 1981; Säwedal 1976; Stur \& Ekrem 2006) and was fairly straight forward for adult males and pupa. Morphology terminology follows Sæther (1980), all measurements were done on $4^{\text {th }}$ instar larvae as described by Stur \& Ekrem (2006).

DNA extraction, PCR and sequencing followed standard protocols and primers at the CCDB and partial COI sequences with all meta-data are registered in the Barcode of Life Data Systems (Ratnasingham \& Hebert 2007). GenBank accession numbers are: Micropsectra insignilobus Kieffer (GU73167-GU73169), Micropsectra logani (Johannsen) (AM398705, GU73170-GU73171), Micropsectra radialis Goetghebuer (GU073172-GU073179), Paratanytarsus austriacus (Kieffer) (AM398749-AM398750, GU073180-GU073185) and Tanytarsus heliomesonyctios (GU073186- GU073192). Neighbour joining analyses were performed with the software Mega4 (Tamura et al. 2007) and utilised the Kimura 2-parameter substitution model in calculation of pairwise distances. Bootstrap analyses included 1000 pseudoreplicates.

Multifocus photography through microscopes has improved image quality of complex three-dimensional structures, and images can in some instances be better and more accurate than drawings in figuring diagnostic features and overall appearances. We used a Leica DM6000 compound microscope fitted with a Leica DFC420 digital camera and connected to a personal computer with Leica Application Suite software including a Montage module to produce the photographic images in this paper. Most images were made in bright field light setting, but some were also made using differential interference contrast. 


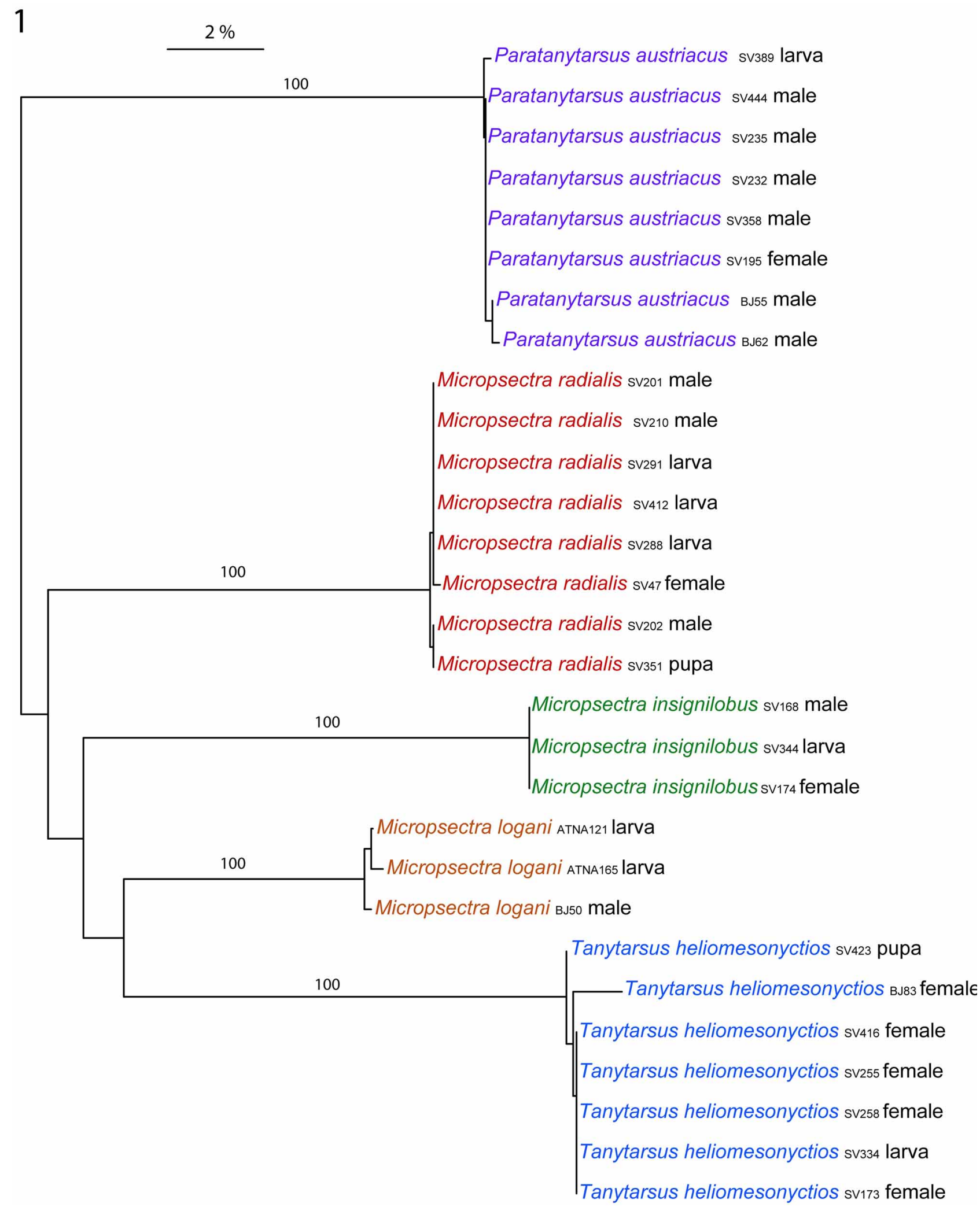

FIGURE 1. Neighbour joining ID-tree based on partial COI-sequences (DNA barcodes) and the Kimura 2-parameter substitution model. Values above branches are bootstrap support. DNA barcodes enabled association of different life stages. 


\section{Results}

So far we have come across five Tanytarsini species on Svalbard. Micropsectra insignilobus, Micropsectra radialis, Paratanytarsus austriacus and the parthenogenetic Tanytarsus heliomesonyctios were all found on Spitsbergen. The fifth Tanytarsini species, the Holarctic Micropsectra logani, has only been recorded from Bear Island, but it is known from Greenland and might be present on Spitsbergen as well.

Neighbour joining analysis of partial COI gene sequences resulted in obvious monophyletic species clusters (Fig. 1) and enabled association of larvae of all Tanytarsini species presently known from Svalbard (Fig. 2-16).

The larval stages from Tanytarsus heliomesonyctios, Micropsectra radialis and Micropsectra insignilobus are described for the first time in our study. The larva of Micropsectra radialis was included in the key for Micropsectra larva (Stur \& Ekrem 2006) but was not further described there. The larvae of Micropsectra logani and Paratanytarsus austriacus have previously been described (Stur \& Ekrem 2006, Klink 1983, Pinder \& Reiss 1983 (fig. $10.55 \mathrm{~A}, \mathrm{C}-\mathrm{G})$ ).

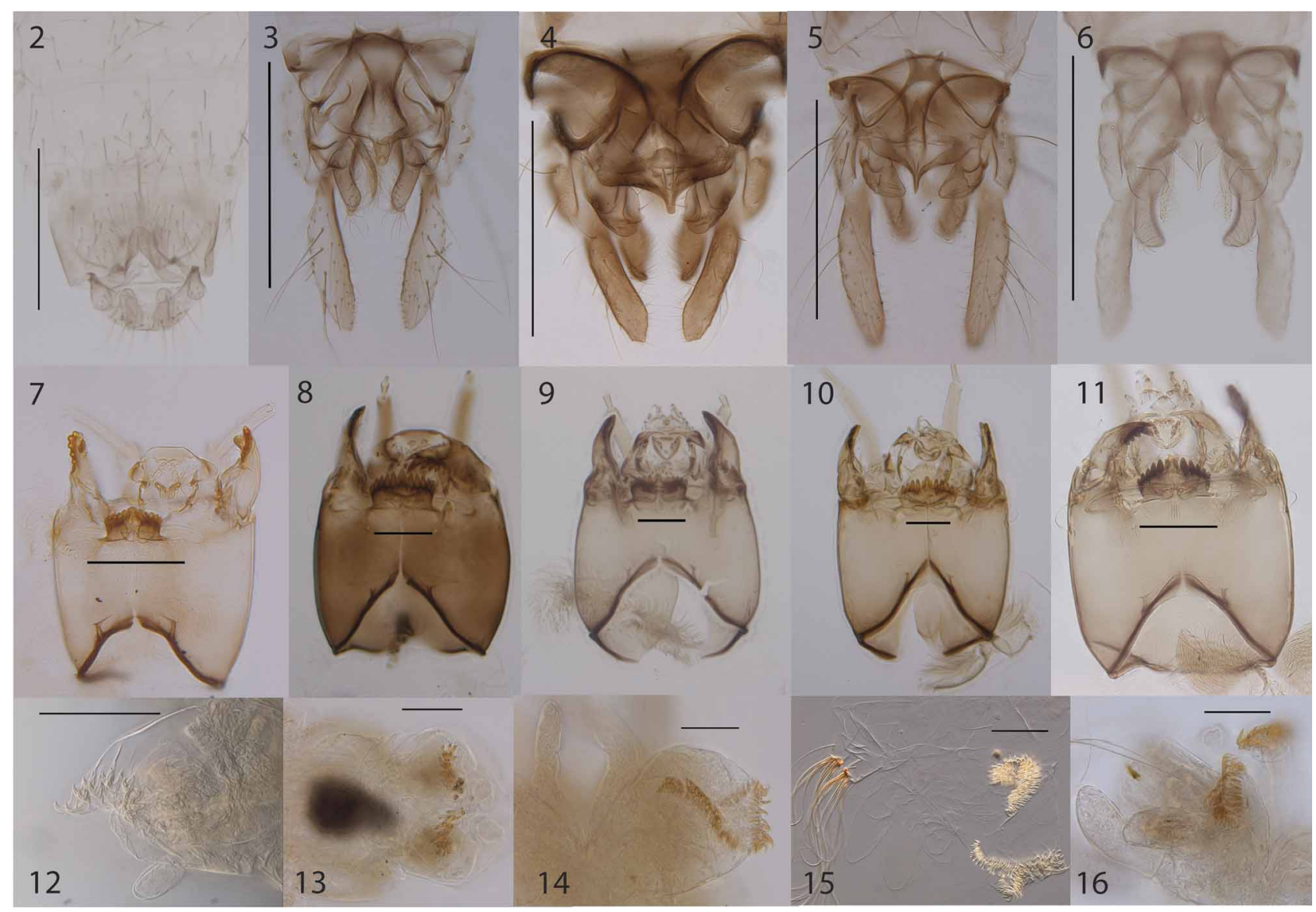

FIGURES 2-16. Tanytarsini of Svalbard, association of adult male hypopygia with larval head capsules and posterior parapods. Columns from left to right: Tanytarsus heliomesonyctios (2, 7, 12), Paratanytarsus austriacus (3, 8, 13), Micropsectra radialis $(2,9,14)$, Micropsectra insignilobus $(5,10,15)$ and Micropsectra logani $(6,11,16)$. Scale bar for hypopygia $=300$ $\mu \mathrm{m}$, for head capsules and parapods $=100 \mu \mathrm{m}$.

\section{Descriptions of larvae}

\section{Micropsectra insignilobus Kieffer, 1924}

Material examined: 7 larvae, Norway, Svalbard, Nordenskioldland, Kapp Linné, Søndre Borgdam, N78.07055 E13.79345 $, 35 \mathrm{~m}, 08$.viii.2008, K. Hårsaker, G. Velle \& T. Ekrem.

Diagnostic characters. Micropsectra insignilobus can be separated from other described Micropsectra larvae by having a moderately long antennal pedestal (c. $120 \mu \mathrm{m})$ including a minute spur $(8 \mu \mathrm{m})$; antennal segment 2 about $1 / 3$ length of segment 1; labral seta SII simple; posterior parapod with about $90-100$ claws in 2-3 rows. 

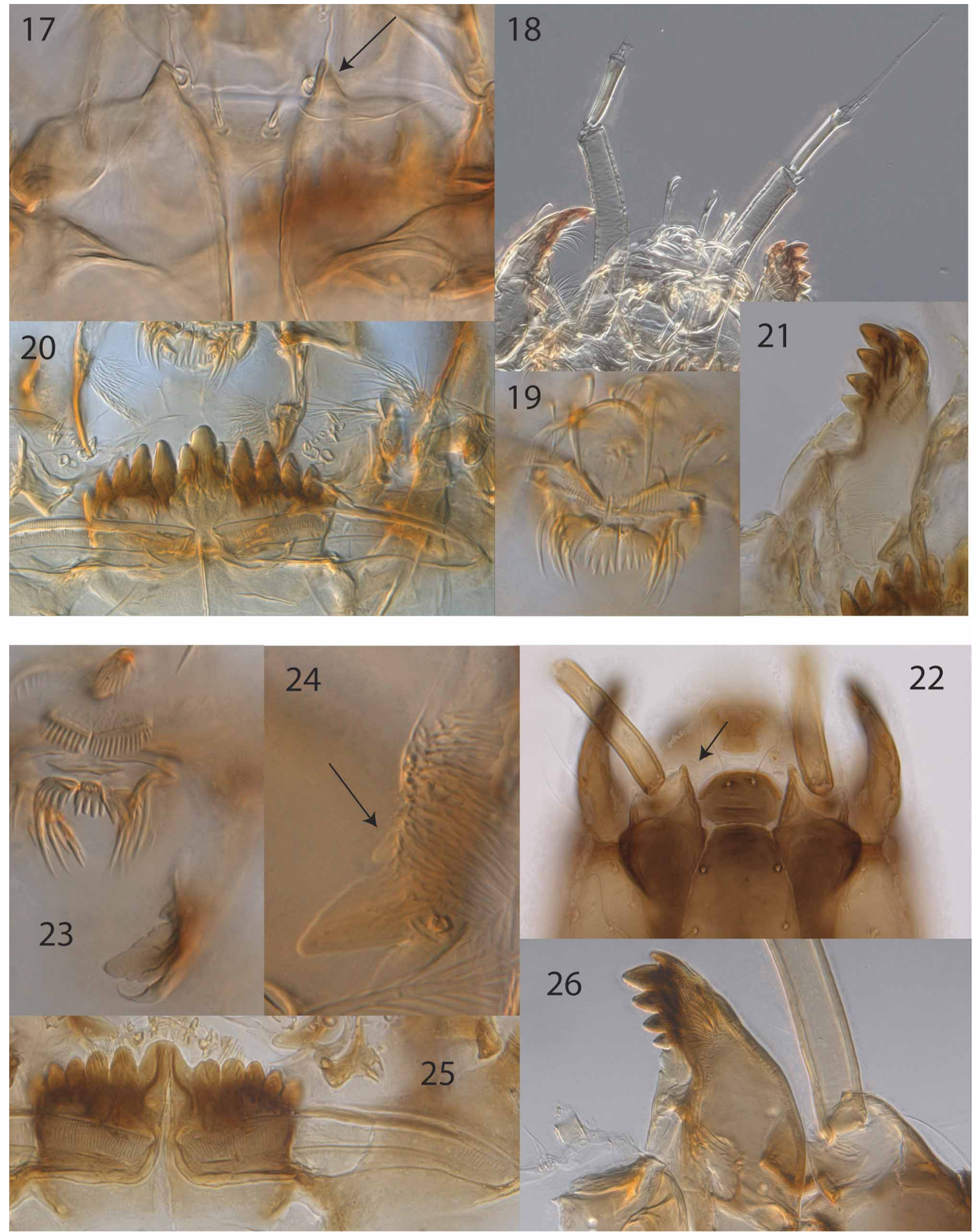

FIGURES 17-26. Larvae. 17-21: Micropsectra insignilobus. 17: spur of antennal pedestal, 18: antenna, 19: pecten epipharyngis, 20: mentum, 21: mandible. 22-26: Micropsectra radialis. 22: antennal pedestal, 23-24: premandible, 25: mentum, 26: mandible. 
Description ( $\mathbf{n}=7$ ). Head capsule (Fig. 10) light yellowish-brown with dark brown posterior margins and mandibular teeth; mentum brown. Live individuals light red. Total length c. $9 \mathrm{~mm}$.

Head capsule length c. $400 \mu \mathrm{m}$, width c. $360 \mu \mathrm{m}$; AR 2.0-2.2, 2.1; AHR 0.27-0.36, 0.31; AAR 0.52-0.72, 0.62 ; antennal pedestal 108-143, $127 \mu \mathrm{m}$ long with $8 \mu \mathrm{m}$ long triangular spur (Fig. 17); antenna with segments 12 well sclerotized, segments 3-5 pigmented, antennal seta placed at about 2/3 length of antennal segment 1 (Fig. 18); lengths of antennal segments (in $\mu \mathrm{m}$ ): 190-211, 203; 70-75, 73; 8-10, 9; 8; 6; Lauterborn organs small, on 125-135, $130 \mu \mathrm{m}$ long pedicels; LOR 5.0-6.0, 5.6; SII simple; chaetae plumose, pectinate; chaetulae simple; S3 simple. Pecten epipharyngis consisting of three scales with tapered, sharp teeth (Fig. 19); premandible with 2 robust teeth, inner tooth broader, brush well developed. Mentum (Fig. 20) about $135 \mu$ m wide, median tooth with obvious notches laterally, about equally strong in colour as lateral teeth; ventromental plates $145 \mu \mathrm{m}$ wide, evenly curved, with obvious striation along whole length; MVR c. 0.93. Mandible (Fig. 21) with 3 inner teeth, one apical tooth, one dorsal tooth; pecten mandibularis slightly convex; postoccipital arch narrow making the well developed, hyaline plate almost triangular in shape (Fig. 10).

Body. Anterior parapods with long, simple spines; posterior parapods with 70-100 simple hooks in two-three rows (Fig. 15); Second lateral seta of abdominal segments 2-7 fan-shaped with c. 20 branches; anal segment with 4 anal tubules, c. $175 \mu \mathrm{m}$ long; procercus with one short and one long dorsal seta, with 4-5 short (c. $600 \mu \mathrm{m})$ and 3 long $(\mathrm{c} .1000 \mu \mathrm{m})$ anal setae.

\section{Micropsectra radialis Goetghebuer, 1939}

Material examined: 2 larvae, Norway, Svalbard, Nordenskioldland, Solryggen, Skartjørne, N77.96194 E13.82041 ${ }^{\circ}, 50$ m, 07.viii.2008, T. Ekrem \& K. Hårsaker; 1 larva Norway, Svalbard, Kapp Linné, Søndre Borgdam, N78.07055 ${ }^{\circ}$ E13.79345 $, 35 \mathrm{~m}, 08$.viii.2008, leg. T. Ekrem \& K. Hårsaker.

Diagnostic characters. Micropsectra radialis can be separated from other described Micropsectra larvae by having a short antennal pedestal $(70-80 \mu \mathrm{m})$ including a short spur; antennal segment 2 about $1 / 4$ length of segment 1; labral seta SII pectinate; labral lamella with < 30 teeth; posterior parapod with more than 100 claws in 2-3 rows.

Description (n = 3). Head capsule (Fig. 9) light yellowish-brown with darker posterior margins, mandibular teeth and mentum. Live individuals light red. Total length c. $10 \mathrm{~mm}$.

Head capsule length c. $430 \mu \mathrm{m}$, width c. $350 \mu \mathrm{m}$; AR 2.2-2.5, 2.3; AHR c. 0.18; AAR c. 0.49; antennal pedestal 70-84, $78 \mu \mathrm{m}$ long with short, triangular spur (Fig. 22); antenna with segments 1-2 well sclerotized, segments 3-5 pigmented, antennal seta placed at about $2 / 3$ length of antennal segment 1 ; lengths of antennal segments (in $\mu \mathrm{m}): 157-163,159 ; 40-46,43 ; 12 ; 6$; 6; Lauterborn organs small, on $60 \mu \mathrm{m}$ long pedicels; LOR c. 2.4; SII simple or slightly pectinate; chaetae plumose, pectinate; chaetulae simple; S3 simple. Pecten epipharyngis consisting of three scales with parallel sided, blunt teeth (Fig. 23); premandible with 2 robust apical teeth and one small basal tooth, middle tooth broadest, brush well developed (Figs 23-24). Mentum (Fig. 25) about $120 \mu \mathrm{m}$ wide; median tooth with lateral notches, tooth becomes rounded appearance in worn menta, somewhat paler than lateral teeth; ventromental plates $155 \mu \mathrm{m}$ wide, slightly more curved laterally, with obvious striation along whole length; MVR c. 0.76; Mandible (Fig. 26) with 3 inner teeth, one apical tooth, one dorsal tooth; pecten mandibularis slightly convex; postoccipital arch broad, rounded, plate not developed.

Body. Anterior parapods with long, simple spines; posterior parapod with more than 100 simple hooks in twothree rows (Fig. 14); second lateral setae of segments 2-7 simple or split in two branches; anal segment with 4 anal tubules, c. $180 \mu \mathrm{m}$ long; procercus with one short and one long dorsal seta, with 5 short (c. $600 \mu \mathrm{m})$ and 3 long (c. $1000 \mu \mathrm{m})$ anal setae.

\section{Tanytarsus heliomesonyctios Langton, 1999}

Material examined: 1 larva, Norway, Svalbard, Nordenskioldland, Kapp Linné, Søndre Borgdam, N78.07055 E13.79345 , 35m, 08.viii.2008, K. Hårsaker, G. Velle.

Diagnostic characters. Tanytarsus heliomesonyctios can be separated from other known Tanytarsus larvae by having the three median teeth on mentum offset and more ventral to rest of mentum; premento-pharyngeal complex normally developed and not heavily sclerotized; mandible with one accessory dorsal teeth and a well developed accessory dorsal plate. 

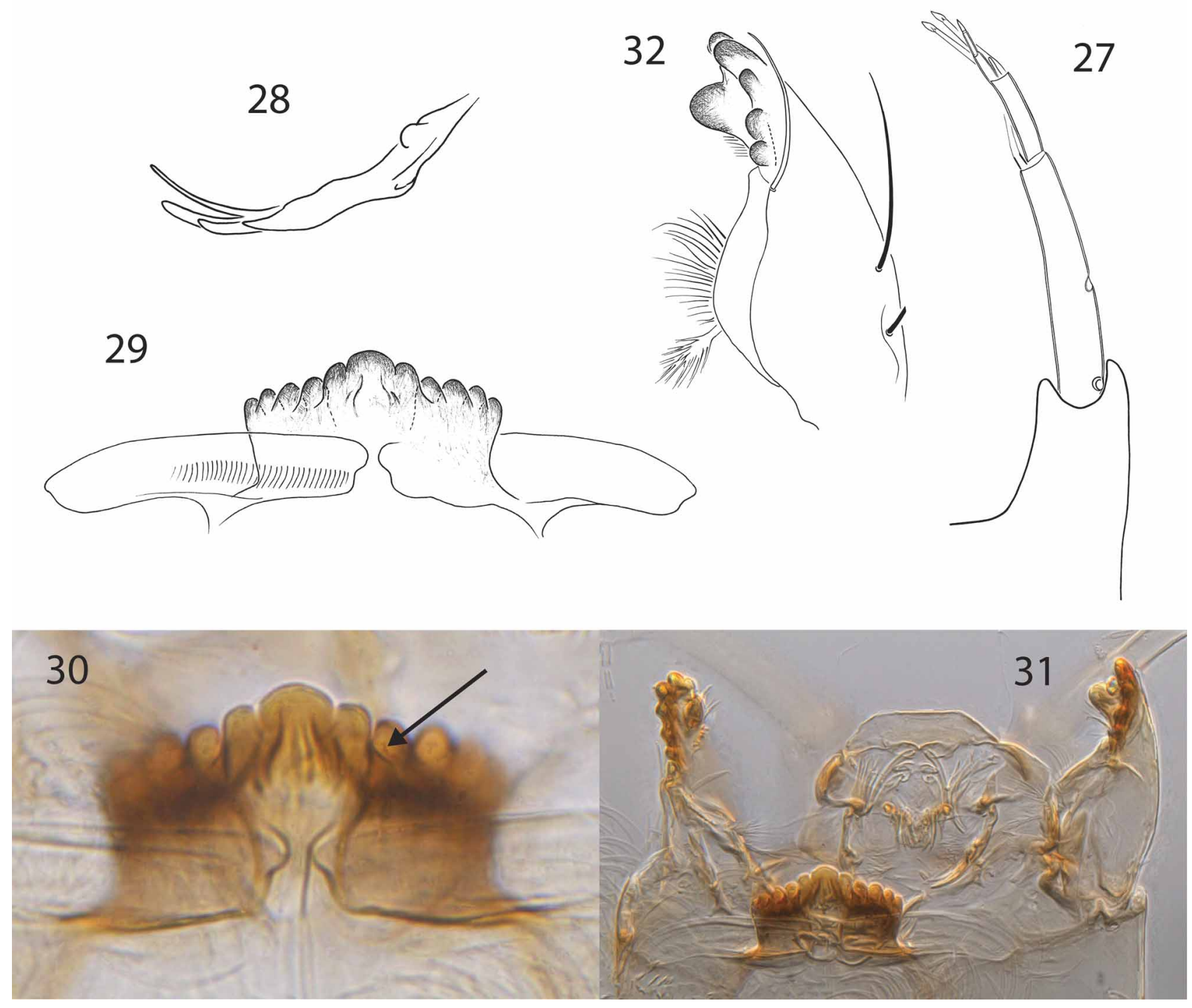

FIGURES 27-32. Tanytarsus heliomesonyctios. 28: premandible, 29-30: mentum, 31: mouthparts ventral view, 32: mandible.

Description $(\mathbf{n}=\mathbf{1})$. Head capsule (Fig. 7) light yellowish-brown with darker posterior margins, mandibular teeth and mentum. Total length c. $4.2 \mathrm{~mm}$.

Head capsule length c. $225 \mu \mathrm{m}$, width c. $200 \mu \mathrm{m}$; AR1.71; AHR 0.34; AAR 1.0; antennal pedestal $76 \mu \mathrm{m}$ long without spur (Fig. 27); antenna with segments 1-2 well sclerotized, segments 3-5 hyaline, antennal seta placed at about $1 / 2$ length of antennal segment 1 ; lengths of antennal segments (in $\mu \mathrm{m}$ ): 76; 24; 10; 6; 5; Lauterborn organs small, on $35 \mu \mathrm{m}$ long pedicels, slightly longer than apex of antenna (Fig. 27); LOR 1.70. SII pectinate; chaetae plumose, pectinate; chaetulae simple; S3 simple. Pecten epipharyngis consisting of three serrate scales; premandible with 4 narrow teeth, brush well developed (Fig. 28). Mentum (Figs 29-31) about $59 \mu \mathrm{m}$ wide, median tooth without notches closely set with first lateral teeth, together with these offset ventrally to rest of mentum; median tooth about same colour as first lateral teeth, slightly paler than remaining teeth; ventromental plates $75 \mu \mathrm{m}$ wide, slightly more curved laterally, with obvious striation along whole length; MVR c. 0.79. Mandible (Figs 31-32) with 3 inner teeth, one apical tooth, two dorsal teeth and one robust dorsal plate; pecten mandibularis slightly convex; postoccipital plate moderately developed, rounded.

Body. Anterior parapods with long, simple spines; second lateral seta of abdominal segments not visible; posterior parapods with about 14 simple hooks in single row (Fig. 12); anal segment with 4 anal tubules, c. $75 \mu \mathrm{m}$ long; procercus with one short and one long dorsal seta, with 3 short (c. $125 \mu \mathrm{m})$ and 5 long (c. $400 \mu \mathrm{m})$ anal setae. 

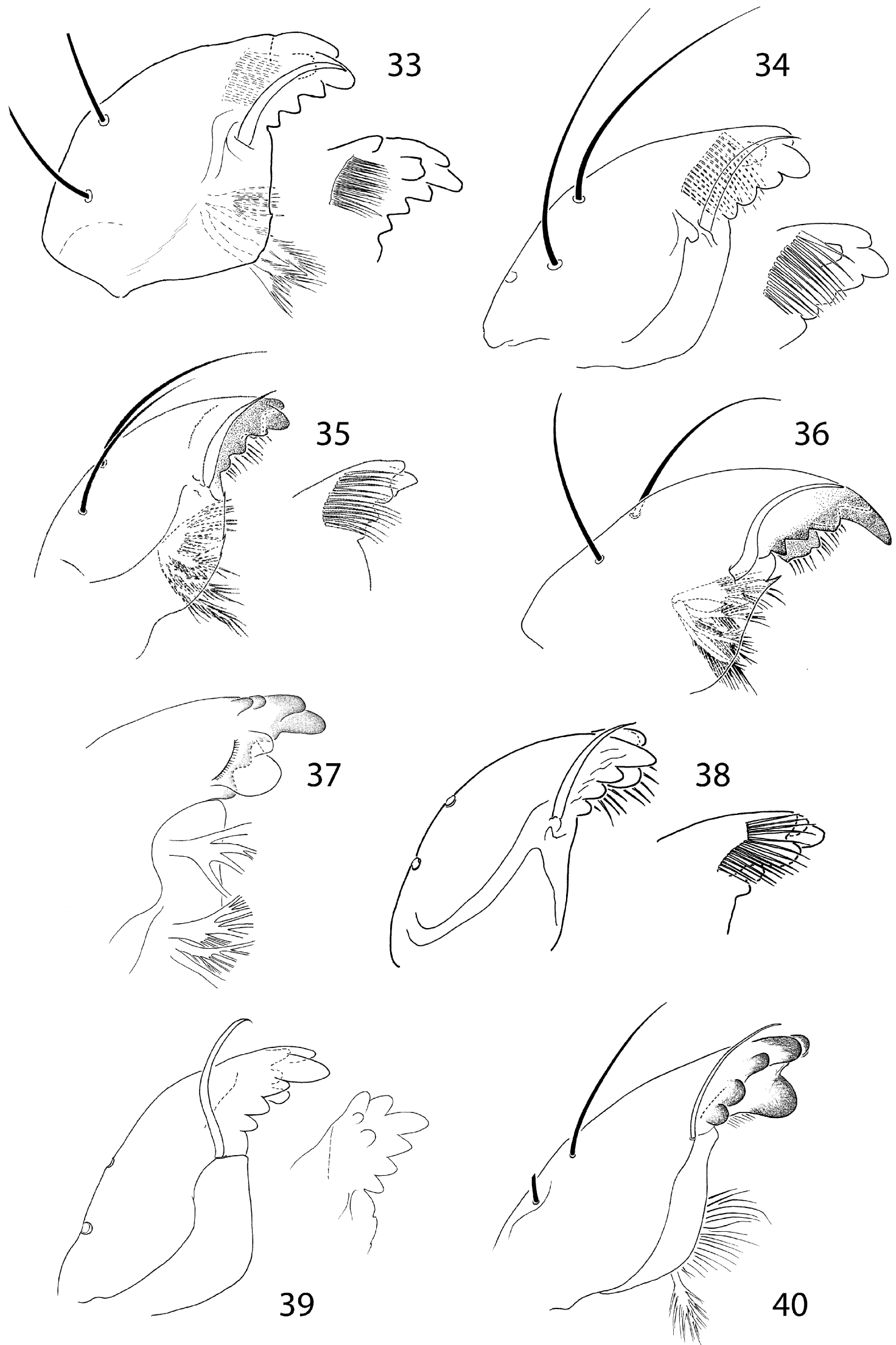

FIGURES 33-40. Tanytarsus larvae mandibles with accessory dorsal teeth. 33: T. lugens, 34: T. bathophilus, 35: T. mancospinosus, 36: T. minutipalpus, 37: T. gracilentus, 38: T. lapponicus, 39: T. recurvatus, 40: T. heliomesonyctios. 


\section{Keys to the Tanytarsini species of Svalbard}

Although these keys comprise the currently known Tanytarsini fauna of Svalbard, caution should be exercised since it is not unlikely that more taxa might be present (e.g. Tanytarsus gracilentus (Holmgren) found circumpolar in the subarctic and Micropsectra borealis Kieffer described from Novaja Zelmja). Female imagines of the subtribe Tanytarsina frequently are impossible to distinguish morphologically on species-level, and they are therefore seldom included in species descriptions. Since the Svalbard fauna currently includes only five Tanytarsini species of three different genera, we have included characters in the key that will separate the adult females of all these species.

\section{Adult}

1. Crossvein $\mathrm{MCu}$ absent; wing membrane with setae, squama bare; cross vein RM almost a straight extension of vein M; midtibial comb present. Males: gonostylus straight and rigidly attached to gonocoxite; gonocoxite with superior, median and infe-

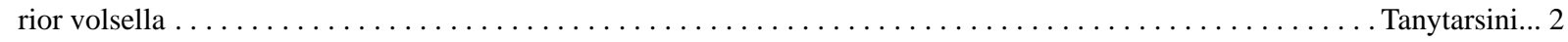
Not the above combination of characters $\ldots \ldots \ldots \ldots \ldots \ldots \ldots \ldots \ldots \ldots \ldots \ldots \ldots \ldots \ldots \ldots \ldots$ other Chironomidae (not keyed)

2. Antenna short with 5-6 flagellomeres; genitalia with cerci, without strongly developed gonocoxites and gonostyli. females...3 Antenna plumose with 11 flagellomeres; genitalia with strongly developed gonocoxites and gonostyli. . . . . . . males... 6 Small, bright green in colour with brown mesonotal bands; tibial combs well separated, each with obvious spur; gonapophysis

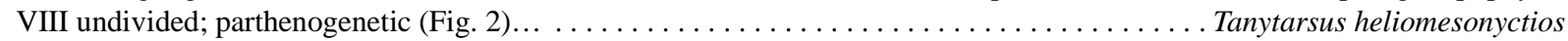
If greenish in ground colour, always with some brown pigmentation (not bright green); tibial combs fused, without or with at

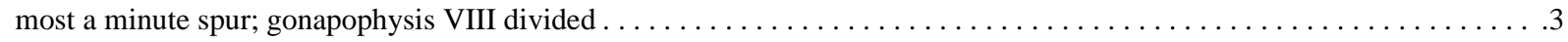

3. Light olive green ground colour, scutellum and antennae; mid and hind tibial combs with minute spur; dorsomesal lobe of

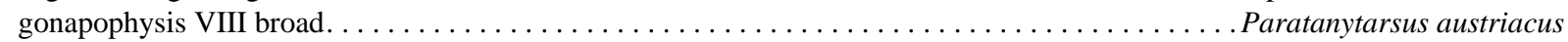
If olive green ground colour and scutellum, antenna, fore tibia and maxillary palps with brown pigmentation; dorsomesal lobe

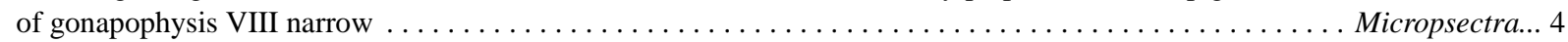

4. Wing membrane with setae in apical $1 / 3$ only, no setae in cell $\mathrm{m}$; low tibial combs; completely dark brown............

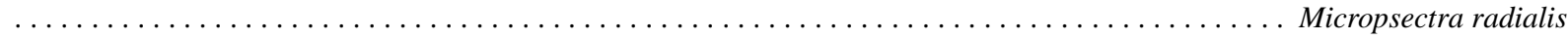
Wing membrane with rich setation, numerous setae in cell $\mathrm{m}$; high tibial combs; dark brown or olive green ground colour. . .5

5. Olive green ground colour, light scutellum, dorsocentrals including humerals $12-15 \ldots \ldots \ldots \ldots$. . . . Micropsectra logani Dark brown species, brown scutellum, dorsocentrals including humerals $15-19 \ldots \ldots \ldots \ldots \ldots$. . . . .

6. Mid and hind tibia combs with minute spur; anal point short and broad with high crests; superior volsella almost square; median volsella well developed, almost reaching tip of inferior volsella, with numerous simple lamellae (Fig. 3) ..........

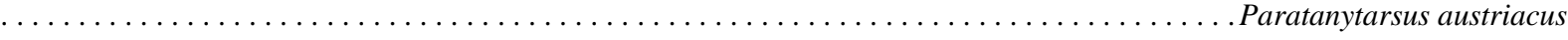
Mid and hind tibial combs without spurs; if anal point broad, never with high crests; superior volsella roundish or fingertiplike in appearance; median volsella of variable length, always with cochleariform lamellae . . . . . . . ...Micropsectra...7

7. Wing membrane with setae in apical $1 / 4$ only; superior volsella with serrate median margin; digitus hooked (Fig. 4) .......

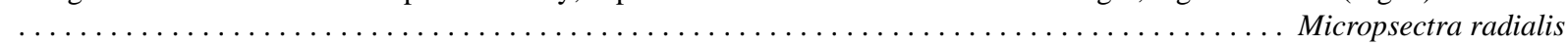
Wing membrane covered with setae; superior volsella with smooth median margin; digitus not hooked $\ldots \ldots \ldots \ldots \ldots$

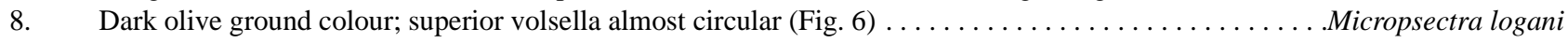
Dark brown colour; superior volsella fingertip-like in appearance (Fig. 5) . . . . . . . . . . Micropsectra insignilobus

\section{Pupa}

1. Anal lobe with fringe of taeniate setae, without macrosetae; tergite II with row of hooklets along posterior margin; at least tergites IV-V with sclerotized patches of points, spinules and/or spines; thoracic horn tubular, simple, without plastron ........

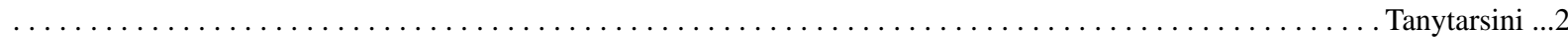
Not the above combination of characters $\ldots \ldots \ldots \ldots \ldots \ldots \ldots \ldots \ldots \ldots \ldots \ldots$ other Chironomidae (not keyed)

2. Thoracic horn well developed, narrow, bare; strong tubercle on pedicel sheath; tergites III-IV with spines in longitudinal, straight patches (Langton 1998 fig. $2 \mathrm{~b}, \mathrm{e}, \mathrm{f}) \ldots \ldots \ldots \ldots \ldots \ldots \ldots \ldots \ldots \ldots \ldots \ldots \ldots \ldots \ldots \ldots \ldots \ldots \ldots \ldots$ Tanytarsus heliomesonyctios Thoracic horn with chaetae or reduced to small bulb; pedicel sheath without strong tubercle; if spines present in patches on

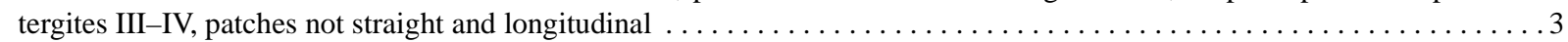

3. Wing sheath with pearl row; spine- and point patches absent from tergite III; tergite IV with one oval, centred point patch ante-

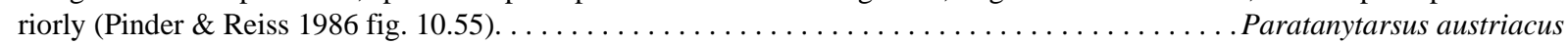
Wing sheath without pearl row; spines or spinules present in patches on tergite III; tergite IV with two point patches .......

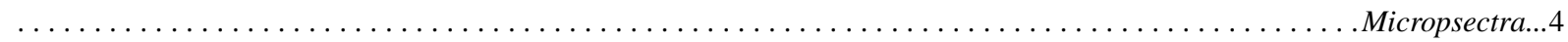

4. Thoracic horn well developed with long chaetae, situated on a dark bulbous base; horn frequently torn off and only bulbous base visible; short spines in small, well separated, posterior patches on tergite III; tergites IV-V with pair of broad, transverse point patches anteriorly (Laville \& Vilchez-Quero 1986 fig. 2, 3) . . . . . . . . . . . . . . . . . Micropsectra radialis Thoracic horn well developed with long chaetae on small, pale base; short or long spines in patches placed medially on tergite III; point patches on tergites IV-V always with longitudinal extensions of shagreen, points or spinules $\ldots \ldots \ldots \ldots \ldots .5$

5. Tergite III with spines ( $>40 \mu \mathrm{m}$ long) in long, laterally curved patches; spines present in longitudinal patches on tergite IV

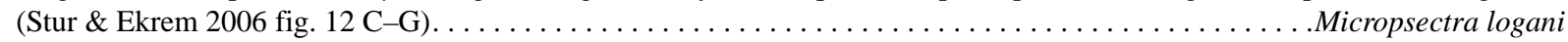


Tergite III with spinules only $(<40 \mu \mathrm{m}$ long) in short patches anterior to seta D5; tergite IV with points in oval, transverse patches with longitudinal extensions of shagreen (Säwedal 1976 fig. 7, 14) . . . . . . . . . . Micropsectra insignilobus

\section{Larva}

1. Antennal pedestals present, obvious; bases of SI fused; SII on long pedestals; ventromental plates well developed broader than width of mentum, separated by less than width of median mental tooth $\ldots \ldots \ldots \ldots \ldots \ldots \ldots \ldots \ldots$ Tanytarsini... 2 Not the above combination of characters $\ldots \ldots \ldots \ldots \ldots \ldots \ldots \ldots \ldots \ldots \ldots \ldots \ldots \ldots \ldots \ldots \ldots \ldots$ other Chironomidae (not keyed)

2. Mandible with conspicuous dorsal plate and additional accessory dorsal teeth; premandible with four teeth (Figs 31-32) .... .

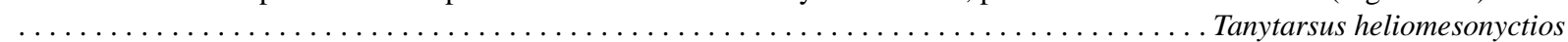
Mandible without dorsal plate and only one dorsal tooth; premandible with two or three teeth $\ldots \ldots \ldots \ldots \ldots \ldots$

3. Head capsule very dark brown (Fig. 8), usually with conspicuous longitudinal stripes dorsally; pecten epipharyngis consists of four digitiform platelets; Lauterborn organs on very short pedicels, not extending beyond apex of antenna; posterior parapod with less than 25 claws (Fig. 13, Pinder \& Reiss 1983 fig. 10.55 A, C-G.) . . . . . . . . . . . . Paratanytarsus austriacus Head capsule brown without conspicuous dorsal stripes; pecten epipharyngis consists of three serrated scales; pedicels of Lauterborn organs extend well beyond apex of antenna; posterior parapod with more than 40 claws. . . . . . Micropsectra ...4

4. Premandible with three teeth (small basal tooth can be difficult to discern, Figs 23-24); antennal pedestal comparatively short (70-80 $\mu \mathrm{m})$; antennal segment 2 about 1/4 length of segment 1; posterior occipital arch broad, plate absent (Fig. 9) . . . . . . .

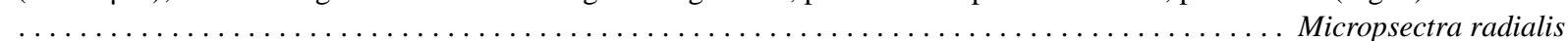
Premandible with two teeth (Stur \& Ekrem 2006 fig. 12 I); antennal pedestal comparatively long (>100 $\mu$ m); antennal segment 2 at least $1 / 3$ length of segment 1 ; if posterior occipital arch broad, plate present . . . . . . . . . . . . . . . . . .

5. Posterior occipital arch narrow, plate well developed, triangular in appearance (Fig. 10); second lateral seta on abdominal segments 2-7 fan-shaped; posterior parapod with more than 70 claws (Fig. 15) . . . . . . . . . . . Micropsectra insignilobus Posterior occipital arch broad, plate moderately developed (Fig. 11); second lateral seta on abdominal segments 2-7 simple; posterior parapod with c. 50 claws (Fig. 16, Stur \& Ekrem 2006 fig. 12 H-L) . . . . . . . . . . . . . Micropsectra logani

\section{Discussion}

The known Tanytarsini fauna of Svalbard is restricted to five species in three genera. This limited diversity makes identification of all major life stages possible with a reasonably good stereo microscope.

The immature stages of some of the species described here have previously been treated (though not sufficiently described) in other publications. Stur \& Ekrem (2006) keyed the larva and pupa of Micropsectra radialis and thereby introduced some characters of diagnostic value, but Schnell (1998) was the first to describe the diagnostic premandible of this species. The pupa of Micropsectra radialis was described by Laville \& Vilchez-Quero (1986) as Micropsectra coracina (Kieffer, 1911) (see also comments in Stur \& Ekrem 2006: 217). Larval fragments of M. insignilobus-type were partly described and keyed in Brooks et al. (2007). Their diagnostic characters for the insignilobus-type larva follow Schnell's (1998) taxonomic comments on the larva of M. insignilobus, but differ from our description of the species by having a broad postoccipital arch. All specimens that we examined had a very narrow postoccipital arch, giving the well developed postoccipital plate a triangular appearance. It is thus possible that the fragments described as insignilobus-type by Brooks et al. (2007) belong to a related species in the speciose notescens-group (see Säwedal 1976).

In previous Malaise trap samples from Svalbard we had records of single Tanytarsus females, but until recently, we were unable to determine the species affiliation. In 2008 we sampled several Tanytarsus pupae and females, and also one larva. These we could associate genetically to each other and the pupa morphologically to Tanytarsus heliomesonyctios Langton, 1998, a parthenogenetic species previously only recorded from Ellesmere Island in the Canadian high arctic.

The only sampled larva of Tanytarsus heliomesonyctios possesses several characters that are worthy of discussion in greater detail. The most obvious feature is the large accessory plate and dorsal tooth on the mandible, characters similar to those seen in a number of other Tanytarsus species, and often grouped as lugens-type by palaeolimnologists. The other interesting feature can be found on the mentum, where the middle three teeth are clearly off-set and placed ventral to the remaining teeth. This particular character has been described as typical for Corynocera oliveri Lindeberg (Hofmann 1984), although similar menta also are recorded for what is classified as lugens-type (Brooks et al. 2007).

The larva of Corynocera oliveri was tentatively associated and described through the finding of a subfossil hypopygium of $C$. oliveri together with head capsule remains in a sediment core sample (Hofmann 1984). The larva of T. heliomesonyctios differs from Hofmann's description of Corynocera oliveri by lacking the notches on 
the median mental tooth and by having one and not two additional dorsal teeth on the mandible. However, these features could be absent from our specimen due to wearing. In any case, our specimen is extremely similar, if not identical, to the taxon described as Corynocera oliveri-type by Brooks et al. (2007, p. 126, figs 7.8-7.10). Thus, we regard it as likely that $T$. heliomesonyctios larvae have been recorded in core samples from the northern Holarctic, but that they have been identified as Corynocera. Given the current distribution of T. heliomesonyctios in the high arctic it is reasonable to believe that the species had a more southern distribution during glacial maxima and climatically cool periods in the Quaternary.

In his preliminary phylogeny of Tanytarsus, Ekrem (2003) discussed the phylogenetic placement of Tanytarsus heliomesonyctios and concluded that the pupa had characters typical for species in both the mendax and the gregarius species groups. Our association of the T. heliomesonyctios larva reveals that probably neither of these two groups contain the most closely related species. Tanytarsus heliomesonyctios clearly has most in common with the lugens-group as larva. Not only due to the mandibular teeth, but also the antennal structure, the pectinate SII on labrum and a comparatively shallow posterior occipital plate is typical for larvae in the lugens-group. The fact that the pupa of T. heliomesonyctios has moderately developed cephalic tubercles and bare thoracic horn also indicates placement in this species group.

There are the eight named species of Tanytarsus known in literature to have additional dorsal teeth on the mandible: T. lugens (Kieffer) (Fig. 33) and T. bathophilus Kieffer (Fig. 34) are representatives of the lugens-group; T. mancospinosus Ekrem \& Reiss (Fig. 35) and T. minutipalpus Ekrem \& Harrison (Fig. 36) belong to the mendaxgroup; T. gracilentus (Fig. 37) was considered to be a member of the norvegicus-group, but has lately been regarded as an own group (Ekrem 2003); T. lapponicus Lindeberg (Fig. 38) is a member of the norvegicus-group; T. recurvatus Brundin (Fig. 39) represents the recurvatus-group (Przhiboro et al. in press); and finally T. heliomesonyctios (Fig. 40) which until now remains unclassified with regard to other Tanytarsus species, but most probably belongs to the lugens-group. In addition, Brooks et al. (2007) described the "glabrescens-type" as separate from the lugens-type mandible by having $2+2$ dorsal teeth and Epler (2001) diagnosed three unassociated larval types with multiple dorsal accessory teeth. One of these (Tanytarsus sp. C) apparently consists of two species; one recently associated with Tanytarsus buckleyi (John Epler pers. comm.). The $2+2$ tooth-arrangement is also found in Tanytarsus recurvatus, and T. buckleyi and T. glabrescens are all regarded members of the recurvatus-group (Reiss \& Fittkau 1971; Sublette 1964; own observation). The number of species with accessory teeth on the larval mandible has increased considerably as more larvae have been associated with other life stages and described. Since obviously unrelated species share the presence of additional dorsal teeth on the larval mandible, this character does not appear to have any value in phylogenetic analyses and classification. Our hypothesis is that structures related to the mandibular teeth are results of adaptive evolution and food choice or perhaps other environmental factors. The fact that similar structures are found in other genera, for instance Goeldichironomus, Stenochironomus and Dicrotendipes, support this view.

\section{Acknowledgements}

Paul Hebert and the staff at the Biodiversity Institute of Ontario, University of Guelph, Canada for sequencing of DNA barcodes and databasing; sequence analysis was enabled by support from Genome Canada through the Ontario Genomics Institute to Paul Hebert. Thanks also to Kaare Aagaard for project initiation, to Renate Bardal for lab assistance and to K. Hårsaker, O. Frengen, M. Skjøstad, R. Solheim, O. K. Berg \& A. Finstad for collecting parts of the material used in this study. We thank John Epler and an anonymous reviewer for their comments on the manuscript.

\section{References}

Boheman, C.H. (1865) Spetsbergens Insekt-Fauna. Öfversigt af Kongliga Vetenskaps-Akademiens Förhandlingar, 22, $563-577$. Brooks, S.J., Langdon, P.G. \& Heiri, O. (2007) The identification and use of Palaearctic Chironomidae larvae in paleoecology. QRA Technical Guide No. 10, Quaternary Research Association, London, 276 pp.

Brundin, L. (1949) Chironomiden und andere Bodentiere der südschwedischen Urgebirgsseen. Ein Beitrag zur Kenntnis der bodenfaunistischen Charakterzüge schwedischer oligotropher Seen. Drottningholm, Lund: Institute of freshwater 
research, $914 \mathrm{pp}$.

Carew, M.E., Pettigrove, V. \& Hoffmann, A.A. (2005) The utility of DNA markers in classical taxonomy: Using cytochrome oxidase I markers to differentiate Australian Cladopelma (Diptera: Chironomidae) midges. Annals of the Entomological Society of America, 98, 587-594.

Coulson, S. \& Refseth, D. (2004) Chapter 3. The terrestrial and freshwater invertebrate fauna of Svalbard (and Jan Mayen). In: Prestrud, P., Strøm, H. \& Goldman, H. V. (Eds.) A catalogue of the terrestrial and marine animals of Svalbard. Norwegian Polar Institute, Skrifter 201, pp. 57 - 122.

Edwards, F.W. (1922) Results of the Oxford University Expedition to Spitsbergen, 1921. - No. 14, Diptera Nematocera. The Annals and magazine of natural history Series 9, 10, 193-215.

Edwards, F.W. (1924) Results of the Merton College Expedition to Spitsbergen, 1923. - No. 14, Diptera Nematocera. The Annals and magazine of natural history Series 9, 14, 162-174.

Edwards, F.W. (1925) Diptera (Nematocera) from Spitsbergen. Results of the Oxford University Expedition to Spitsbergen, 1921. The Annals and magazine of natural history Series 9, 16, 354-356.

Edwards, F.W. (1935) Diptera from Bear Island. The Annals and magazine of natural history Series 10, 5, 531-543.

Ekrem, T. (2003) Towards a phylogeny of Tanytarsus van der Wulp (Diptera: Chironomidae). Is morphology alone sufficient to reconstruct the genealogical relationship? Insect Systematics and Evolution, 34, 199-219.

Ekrem, T., Stur, E. \& Hebert, P.D.N. (2010) Females do count: Documenting Chironomidae (Diptera) species diversity using DNA barcoding. Organisms Diversity \& Evolution, 10, 397-408.

Ekrem, T., Willassen, E. \& Stur, E. (2007) A comprehensive DNA sequence library is essential for identification with DNA barcodes. Molecular Phylogenetics and Evolution, 43, 530-542.

Epler, J.H. (2001) Identification Manual for the Larval Chironomidae (Diptera) of North and South Carolina. North Carolina Department of Environment and Natural Resources and St. Johns River Water Management District, Special Publication SJ2001-SP13. Raleigh, North Carolina, p. 526.

Goetghebuer, M. (1933) Chironomides du Groenland oriental, du Svalbard et de la Terre de François Joseph. Skrifter om Svalbard og Ishavet, 53, 19-31.

Goetghebuer, M. (1939) Ceratopogonidae et Chironomidae nouveaux ou peu connus d'Europe (Dixième Note). Bulletin et Annales de la Société Entomologique de Belgique, 79, 379-389.

Hebert, P.D.N., Penton, E.H., Burns, J.M., Janzen, D.H. \& Hallwachs, W. (2004) Ten species in one: DNA barcoding reveals cryptic species in the neotropical skipper butterfly Astraptes fulgerator. Proceedings of the National Academy of Sciences of the United States of America, 101, 14812-14817.

Hofmann, W. (1984) A subfossil record of the presumed larva of Corynocera oliveri Lindeberg from the Lobingsee (Swiss Plateau). Studies in the Late-Quaternary of Lobingsee 8. Spixiana, 7, 211-214.

Holmgren, A.E. (1869) Bidrag til Kännodomen om Beeren Eilands och Spetsbergens Insekt-Fauna. Kungliga Svenska vetenskapsakademiens handlingar, 8, 1-55.

Kieffer, J.J. \& Thienemann, A. (1919a) Chironomiden, gesammelt von Dr. A. Koch (Münster i. W.) auf den Lofoten, der Bäreninsel und Spitzbergen (Dipt.). Entomologische Mitteilungen, 8, 38-48.

Kieffer, J.J. \& Thienemann, A. (1919b) Chironomiden, gesammelt von Dr. A. Koch (Münster i. W.) auf den Lofoten, der Bäreninsel und Spitzbergen (Dipt.). Entomologische Mitteilungen, 8, 110-124.

Kieffer, J.J. (1924) Quelques nouveaux chironomides de Scandinavie. Annales de la Societé scientifique de Bruxelles, 44, 8086.

Klink, A.G. (1983) Key to the Dutch larvae of Paratanytarsus Thienemann \& Bause with a note on the ecology and the phylogenetic relations. Medeklinker, 3, 1-36.

Langton, P.H. (1998) [distributed 1999] Micropsectra silvestrae n. sp. and Tanytarsus heliomesonyctios n. sp., (Diptera: Chironomidae), Two parthenogenetic species from Ellesmere Island, Arctic Canada. Journal of the Kansas Entomological Society, 71, 208-215.

Laville, H. \& Vilchez-Quero, A. (1986) Les Chironomidés (Diptera) de quelques "lagunas" de haute altitude de la Sierra Nevada (Granada, Espagne). Annales de Limnologie, 22, 53-63.

Norwegian Polar Institute (2009) Bjфrnфya. Norwegian Polar Institute. Available from: http://npweb.npolar.no/geografi/bjornoya (September 25, 2009).

Oliver, D.R. (1962) A review of the subfamily Orthocladiinae (Chironomidae, Diptera) of Bear Island. Astarte, $20,1-19$.

Pinder, L.C.V. \& Reiss, F. (1983) 10. The larvae of Chironominae (Diptera: Chironomidae) of the Holarctic region. - Keys and diagnoses. In: Wiederholm, T. (Ed.) Chironomidae of the Holarctic region. Keys and diagnoses. Part 1. Larvae. Entomologica scandinavica Supplement, 19, pp. 293-435.

Pinder, L.C.V. \& Reiss, F. (1986) 10. The pupae of Chironominae (Diptera: Chironomidae) of the Holarctic region. - Keys and diagnoses. In: Wiederholm, T. (Ed.) Chironomidae of the Holarctic region. Keys and diagnoses. Part 2. Pupae. Entomologica scandinavica Supplement, 28, pp. 299-456.

Prestrud, P., Strøm, H. \& Goldman, H.V. (2004) Introduction. In: Prestrud, P., Strøm, H. \& Goldman, H. V. (Eds.) A catalogue of the terrstrial and marine animals of Svalbard. Norwegian Polar Institute, Skrifter 201, pp. 1-4.

Przhiboro, A., Ekrem, T. \& Stur, E. (in press) Bionomics and taxonomy of Tanytarsus recurvatus Brundin, 1947. Wang, X. et al. (Eds.) Proceedings of the $17^{\text {th }}$ International Symposium on Chironomidae.

Ratnasingham, S. \& Hebert, P.D.N. (2007) BOLD: The Barcode of Life Data System (www.barcodinglife.org). Molecular 
Ecology Notes, 7, 355-364.

Reiss, F. \& Säwedal, L. (1981) Keys to males and pupae of the Palaearctic (excl. Japan) Paratanytarsus Thienemann \& Bause, 1913, n. comb., with descriptions of three new species (Diptera: Chironomidae). In: Cederholm, L. (Ed.) Advances in insect systematics and phylogeny. Entomologica scandinavica Supplement, 15, 73-104.

Sæther, O.A. (1980) Glossary of chironomid morphology terminology (Diptera: Chironomidae). Entomologica scandinavica Supplement, 14, 1-51.

Säwedal, L. (1976) Revision of the notescens-group of the genus Micropsectra Kieffer, 1909 (Diptera: Chironomidae). Entomologica scandinavica, 7, 109-144.

Schnell, Ø.A. (1998) Guidelines for identification of chironomid larvae in the MOLAR project, NIVA Report, SNO 3710-97, Norwegian Institute for Water Research, $23 \mathrm{pp}$.

Stur, E. \& Ekrem, T. (2006) A revision of West Palaearctic species of the Micropsectra atrofasciata group (Diptera: Chironomidae). Zoological Journal of the Linnean Society, 146, 165-225.

Sublette, J.E. (1964) Chironomidae (Diptera) of Lousiana I. Systematics and immature stages of some lentic chironomids of West-Central Lousiana. Tulane Studies in Zoology, 11, 109-150.

Tamura, K., Dudley, J., Nei, M. \& Kumar, S. (2007) MEGA4: Molecular evolutionary genetics analysis (MEGA) software version 4.0. Molecular Biology and Evolution, 24, 1596-1599. 